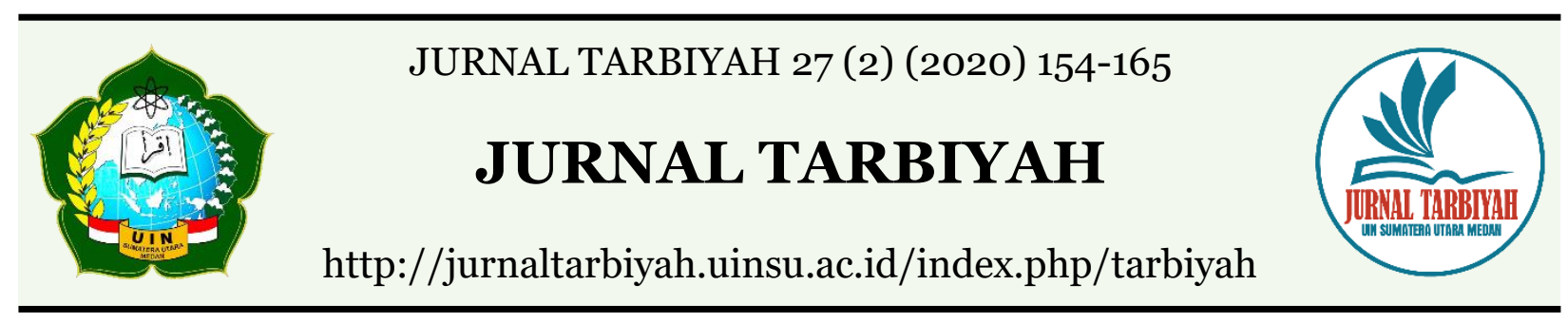

\title{
LIVING CURRICULUM CONCEPT IN SIKL (INDONESIAN KUALA LUMPUR SCHOOL)
}

\author{
Mohamad Faisal Subakti', Partono², Laily Rizqi Amalia3, \\ Nor Faela Shofa Afrida4, Zumratun Nisak5 \\ 1,2,3,4,5 IAIN Kudus, Kudus, Indonesia \\ Email: 1partono@iainkudus.ac.id, 2kaksub4224@gmail.com, \\ 3lailyrizqiamalia415@gmail.com, 4nor.faelashofa18@gmail.com, \\ 4zumrotunsaja981@gmail.com
}

DOI : 10.30829/tar.v27i2.822

Accepted: October 23th, 2020. Approved: December 25th, 2020. Published: December 31th, 2020

\begin{abstract}
This study aims to explain the concept of a living curriculum when it is applied in educational institutions. Indonesian Kuala Lumpur School is as an example of the concept of a living curriculum School. Specifically, this study discusses about the concept of a living curriculum as a curriculum which is relevant to the growing era. It is suitable, if it applied in the the industrial era 4.0 to face the industrial era 5.0. This study was structured by using a systematic literature review method which is aimed to identify and interpret research results related to the living curriculum. Meanwhile, the data analysis technique uses the flow model, proposed by miles and hubermen. it includes data reduction, data presentation, and conclusion drawing. The results of this study indicates the importance of curriculum development which must stay relevant to the progress of the times, in producing of superior students and have global competitiveness.
\end{abstract}

Keywords: SIKL, Living Curriculum, Character Building, Life Skill 


\section{INTRODUCTION}

Science and technology in the 4.0 era, undergone rapid development and progress. Thus, it demands changes in various aspects of life include to education. These changes involve the changing of the education concept of education which must be adapted to the progress of the times, which will also lead to changes in the curriculum. It is not surprising, when we often undergone the changing of curriculum in Indonesia. This situation emerge an idea or concept to develop permanent curriculum. But, it can be adaptive based on the progress of the times practically. Some education experts called this as living curriculum.

Living curriculum is an approach in learning. it is dynamic by involving many parts related to the education. Another characteristic of this curriculum is life, it means that it can be adjusted to conditions and repeated interactively as well as stop the repetition when the conditions are met. (Abdullah, 2011). Dynamic and nature are the important to develop curriculum in this era. Curriculum is the core in education. education cant achieve the goal without the curriculum. In implementing the living curriculum, curriculum organization is very necessary, because it is related to the arrangement of learning materials that have an impact on the administrative implementation of the learning process. Besides that, the living curriculum is also a new curriculum model which has different from the previous curriculum. This difference can be seen from changes in the curriculum model that are more adapted to the current development.

Related to this, Indonesian Kuala Lumpur School is also developing a living curriculum. They aim to equip their students to compete the era in the future. Therefore, students must have cognitive, affective, and psychomotor abilities. The development of the living curriculum at the Indonesian Kuala Lumpur School emphasizes on character building and life skills. Another goal of developing is the growing of collaboration between the parents of students and the school in educating children, so that they have the ability to have life skills and good character, at home, at school, and in the community (Mariani, 2020). In this study, it will discuss in detail related to the development of a living curriculum at the Indonesian Kuala Lumpur School, especially a deeper exploration of character education and life skills toward students 


\section{LITERATURE REVIEW}

\section{Definition of Living Curriculum}

Based on the language, living curriculum is consists of two words; living, it means life, and curriculum means a set of subjects. Widely, the curriculum is a set of plans and arrangements related to materials and learning sources, content, and methods that can be used as instructions for implementing teaching and learning activities, to achieve educational goals. The curriculum can also be understood as an educational institution program to the students. Based on this program, students can carry out various learning activities, which support their growth and development (Lismina, 2018).

In the concept, living curriculum is dynamic learning which involves many parts related to education. The goal is to get new ideas in the learning process. The living curriculum focused on a holistic learning process in building of a knowledge framework through learning approach. It focuses on the process of understanding information and elaborating on other topics (Kanal Information, 2020). In conclusion, Living Curriculum is a vivid curriculum model which is adaptable, dynamic and adaptive.

\section{Pedagogy and Basic Living Curriculum Concepts}

Pedagogy in terms of language, comes from Greek, namely Paidos (children) and Agego (to lead), thus in terms of Pedagogy is to lead children. Pedagogy can also be understood as theory in teaching. The teacher tries to understand the materials for teaching, gets to know students more closely and determines how to teach them. According to Sudarwan Danim, pedagogy is also related to learning and the relationship between teaching and learning (Hiryanto, 2017).

Thus, a good pedagogy is an effective pedagogy which tries to combine several alternatives in learning strategies, support for intellectual involvement, has relationship with the wider world, and a comfortable classroom environment. These concepts are the basis for developing the pedagogy of the living curriculum. Because of this curriculum is flexible in the learning process and student center approach, teaching learning process can be active in the classroom. Through of these, the developing learning skill is more dominant than memorizing of the subject matter.

Living curriculum pedagogy focuses on developing adaptive skills rather than classical skills. Adaptive skils are the ability to gain new understandings are applied in their daily lives. Thus, this differs from most curriculum models, which still develop classical skills with a focus on in-depth knowledge of the domain and the subject matter. 
Adaptive skills are closely related to adaptive behavior. It is a level where individuals are able to behave based on individual standards of freedom, so that they can adjust to the norms that apply in their environment. Automatically,it is not everyone has adaptive behavior, because this is influenced by several factor such as; environment, intelligence, emotion and social support (Carina and Supriyadi, 2016).

Basically, the pedagogy of the living curriculum that has been developed and applied in several schools, such as in Tremont. It consists of seven principles; 1) Focusing on skill development, 2) Viewing students as motivated and full of plans, 3) Centered on epistemic emotions (the desire to find out something he/she likes), 4) Assuming that social and emotional learning is very important for all subjects, 5) Adjusted to the needs of students that are relevant to the times, 6) Collaboration with various parties 7) Dynamic in nature, and can be changed in line with the progress of the times (Grotzer, et al, 2019).

In concept of a living curriculum can help students assess what they do and what they don't know. In this case, students must be competent, having many plans, and motivated. Learners are encouraged to self-regulate and develop an awareness of their affective and cognitive needs. Teachers can help students to increase enthusiasm in learning and develop appropriate strategies to understand learning material easily. The relationship between teachers and students is mutual respect, teachers have expertise in the nature of learning and the important participants in the learning process (Grotzer, et al, 2019).

Developing and having a variety of skills among other students is also an important aspect of the living curriculum approach. In this case, students must respect each other and feel confident in their special skills. Students also have to work hard to hone their areas of expertise. In essence, living curriculum has great approach which focuses on the strengths, interests and learning styles of the individual (Tremont, 2017).

In concept the living curriculum, it is similar to the 2013 curriculum which is designated as the national curriculum. Both of them are developed to deal with various educational problems and challenges in the future. In facing these challenges, the curriculum must be able to provide students with a variety of competencies that are adapted to the development and progress of the times. For example, the ability to communicate, think critically, have a global perspective, readiness to work, and responsibility for the environment (Chasanatin, 2015). However, in terms of flexibility, the living curriculum is more flexible than the 2013 curriculum. For example, the 
application of the living curriculum at Tremont School is very flexible. Lliving curriculum is arranged through weekly contracts. Contracts is a menu that offers a list of academic and social tasks in which every student should obey in Tremont School. Students can decide their time to solve math problems, reading, or project-based work. Teachers can give students a choices about how and when they should learn, as well as strong responsibility for their learning. Even though the contract is actually made by the teacher, but it based on student center approach. For example the teacher says "Everyone, please take your math test", then students can come to the teacher when they are ready to do the test by saying: "Can I take my math test? ", In this case the educator diverts the initiative to students, not asking students directly to work on the subject matter (Tremont, 2017).

It can be concluded that the pedagogy and basic concepts of the living curriculum are related to the purpose of the living curriculum itself; to breathe new life into the learning process for each student, or give freedom to students in the learning process based on their wishes and interests, but teacher designed the rules to the students.

\section{RESEARCH METHOD}

This study is conducted by using the Systematic Literature Review (SLR) method. This aimed to evaluate, identify and interpret research results related to a particular focus area. Research using the SLR method is divided into three stages; planning, implementation, and reporting (Latifah and Ritonga, 2020). At the planning stage, there are several things; planning and identifying research requirements. Then, the implementation stage includes to identifying of questions, searching of strategies, selection process based on specified criteria and determining the data. Next, they come to the final stage of reporting; writing the final results of the research, based on the processing of various literatureto complete and obtain the systematic research results.

This research data comes from two sources. They are primary data sources (main) and secondary data sources (additional). The primary data source came from the International online KKL activities at the Indonesian Kuala Lumpur School. Meanwhile, secondary data sources come from the web, journals, books, and scientific articles relevant to the theme of this study. The data collection technique is done by exploring the Internet, starting from the Google Scholar, Doaj, Moraref, and Garuda Ristekdikti sites. Meanwhile, the data analysis technique used the flow model proposed by Miles and Hubermen. By following this model, there are three data analysis activities that must be 
carried out; data reduction (focusing on the data obtained), displaying data (displaying the data obtained), and drawing conclusions (Yusuf, 2014).

\section{RESULTS}

Conceptually, a living curriculum is an educational program whose the implications in the guidance, advising and habituation of students about the value, goal and meaning of life. Through this curriculum, students can realize how important to behave based on rules and good values. The Living Curriculum is also an activity to develop or stabilize the character and good values possessed by students, it makes students has complex principle for a harmonious relationship between humans and their surroundings (Moh. Faizin, 2019).

The concept of living curriculum is very appropriate to be implemented in educational institutions by using an open environmental model and supports the development of students independently. The characteristics of the living curriculum include a comprehensive understanding between teachers, students, the social community and other. In developing of living curriculum, there are also four principles (Omeri, 2015). According to emori, they are; 1) Generating creative and innovative ideas, 2) Generating a sense of enthusiasm or curiosity of students in order to build a foundation of learning experiences, 3) Integrating practice, knowledge, and skills development in the learning process, to build a pleasant learning atmosphere, relaxed and conducive 4) Doing face-to-face activities with a variety of learning models.

The Application of living room concept at the Indonesian Kuala Lumpur School, focused on character education and development of life skill. In this case, the main hope of the Indonesian Kuala Lumpur School is wishing to promote the nation's next generation by referring to the motto " Civilized is First Then Knowledge ". Therefore, the first and main point in the concept of the living curriculum at Indonesian Kuala Lumpur School is character education. Character education is a process of cultivating the value of goodness in students. Character education can also be understood as education that develops noble character in students. A student can be said to have character if his behavior is based on good moral principles (Zafi and Partono, 2020). Therefore, character is closely related to Morals. According to Imam Al-Ghazali, Moral is an order which is deeply embedded in the soul by bringing out good or bad deeds without requiring thought or consideration or even a decision. Moral education is the same as character education. This education starts from the family. The family or parents is a model for children. They 
see, learn and follow the model in their family. (Partono, 2020). However, teacher also has a major role in educating the character of their students in school. The existence of a character education program has great role at school, students can complete their character and train their intellectual abilities. Thus, schools can create a generation is knowledgeable and civilized (good character) and can also provide benefits to the surrounding environment. In line with this, Zubaedi argues that character education is an effort in intellectual cultivation to shape experiences, attitudes, and behaviors based on the values and norms prevailing in society (Hayati, 2015).

Thus, it can be indicated that character education is a unified system to instill good values to the students which involves; desire, awareness, knowledge, or action in order to carry out these values (Mustoip, et al., 2018). Reflecting on existing problems, including problems of moral values, such as; 1) Errors in parenting parents, 2) Low level of comfort, 3) Greed and the nature of materialism that shapes the life values of adolescents, 4) Low consideration of good morals, 5) And, reduced moral knowledge which results in ethical blindness. Lack of moral in adolescents is as the results of cognitive shut down symptoms. Then, it continues to uncontrollable action. All of these demands, ideals, and problems indicate the importance of character or moral education to every student. Reflecting on these problems, a living curriculum was compiled among others to overcome these problems.

The concept of implementing a living curriculum in the Indonesian Kuala Lumpur School has its own background. In the current conditions of Covid-19, the application of the living curriculum in Indonesian Kuala Lumpur School emphasizes optimizing of IT in learning and equipping students about the meaning of responsibility as the principle of character education during home study. The teacher in Indonesia Kuala Lumpur School stay trying to provide assistancend and have prepared many instruments to be applied to the students during learning from home. The development and application of the living curriculum at the Indonesian Kuala Lumpur School in the future is intended to equip students to compete based on their times, because the future of students is very different if we compare to the present.

Kuala Lumpur Indonesian School the concept of living curriculum which are related to character education. it supported to many things. The one of the most excellent programs is the honesty canteen program. Canteen is a facility or place that provides food and drinks used within agencies, organizations, and schools. Canteen is basically a place to sell food and drinks, but more than that, the canteen can be a fairly appropriate 
tool to train student honesty. Another example of excellent programs is Class without pickets. It means that classes without pickets are one of the programs that aim to train responsibility, discipline, and cooperation of students. This could happen because the level of awareness of students at the Indonesian Kuala Lumpur School towards the environment is higher than students in Indonesia. As said by Mrs. Himmatus Sya'adah as Curriculum officer at Indonesian Kuala Lumpur School, that "There is a differences of situation and challenging between students at the Indonesian Kuala Lumpur School and students in Indonesia " ( BKPI, 2020). Even though there is no picket, cleanliness is the responsibility and obligation of students at the Indonesian Kuala Lumpur School, because they are aware that a clean class will make them more comfortable and and this learning brought them into their home ( Martanti, 2017).

Besides the character education, life skills are also a major highlight in the development of the living curriculum at Indonesian Kuala Lumpur School. According to the Ministry of National Education, a life skill is someone who has certain skills or expertise, and the basic ability to support it. As the examples are the ability in reading, calculatting, planning, problem solving, managing of resources optimally and work in teams. Meanwhile, according to Anwar, life skill is the provision of skills and abilities related to business opportunities that exist within the community. According to Brolin, life skill is defined as the interaction of a variety of knowledge and skills that are very important for a person to master. People can live a good and independent life without depending on other people. Kevin Davis defines life skills can help students learn, how to live, grow into good personalities, cooperate with others, and can make logical decisions so that they can finally achieve goals in life (Wahab, 2012). Thus it can be concluded that skill is a skill or skill in living life and can actively or creatively solve existing problems.

The development of life skills in education aims to make students live and able to live in the midst of globalization. The existence of life skills can increase student participation in real life (Anggraini, 2018). According to Jecques Delor, explain that life skills have four foundations of learning (Baruwadi, 2012) they are; 1) Learning to acquire knowledge, 2) Learning to do something, 3) Learning to be useful people, and 4) Learning to live side by side. In line with this, life skills are one of the main points in the development of a living curriculum at the Kuala Lumpur Indonesian School, the goal is that students master life skills. It can make it easier for students to achieve a better standard of life. 
One example of developing life skills that is relevant to zama progress is skills in entrepreneurship. Entrepreneurship is someone who is able to see opportunities that make something creative and possibilities to start something new (Alfianto, 2012). According to Yuyus entrepreneurship is determined by the character and traits within a person through strong abilities to realize his ideas and ideas into the real world. Through entrepreneurship, it is expected to be able to make character is not only as a business but to be creative, innovative and brave in making decisions (Wulandari, et al., 2016).

The development of life skills will be easier if it is accompanied by the implementation of the $4 \mathrm{C}$ concept in learning, because this concept has proven to be effective in helping to develop the life skills possessed by students. The $4 \mathrm{C}$ concept includes; First communication, it is an activity carried out by two or more people who use information as an intermediary medium to communicate, usually communication is carried out orally or in another language. Communication is an activity that is very often done to communicate. Because communication is very important for human life with communication, we become more understanding to the information. Interaction means of communicating is not only with words but can be done through mimicry, such as smiling, waving it in front of the eyes or intuition. Communication skills include all skills in conveying thoughts clearly in a written or oral.

Second, Collaborative Learning, it involve students in a group to form knowledge and achieve educational goals through social interaction. Collaboration is team collaboration that can be developed through experiences and events. Students can do all work together through assignments or projects to develop their skills.

Third, Critical thinking and Problem solving. Thinking is a natural nature from God to every human being. Critical thinking is a series of processes that are clearly directed and can be used to solve problems as well as making decisions by analyzing indepth and conducting further research. Critical thinking skills include all abilities that can access and analyze information. It can be used as a lesson and trained to master this learning. Someone who can think critically is someone who is able to find various solutions from a variety of points of view. They can also express their opinions based on the manner of communication

Fourth, Creativity and Innovation. According to Lauren, creativity is an idea of someone's thinking which is innovative and different from others. Achieving success also requires very high skills in innovation and creation. Student can develop their creativity through their thinking. The successful also can be seen from the creativity and uniqueness 
skill. These make them different from the abilities possessed by others generally (Septikasari and Frasandy, 2020). Through of this way, students can master the $4 \mathrm{C}$ concept well and they can automatically optimize their life skills.

Basically, the development of a living curriculum at the Kuala Lumpur Indonesian School is correct and accurate step to prepare a curriculum in forming of good character. The two things are the main key to success in the present era. Because no matter how smart and good someone is, if they don't have good character, such as courtesy, responsibility, respect, and so on, it can prevent someone from succeeding. Curriculum development should be a role model for national curriculum development. Because the current curriculum still only focuses on the cognitive aspects. Students are required to get the best grades. Even though in the current era, good values cannot guarantee someone to be successful. But someone having qualified skills with good character, it can make it easier for someone to reach successful.

\section{CONCLUSION}

Living curriculum is dynamic learning approach. They involve students, teachers, social community, and other institutions related to education. The collaboration from them was able to get new ideas in the teaching and learning process. Living curriculum is a permanent curriculum, but in the implementation can be adaptive based on the times. The main objective of developing a living curriculum is to increase personal understanding of subject matter by using an integrated process of discovery, collaborative work, develop skills, encouraging exploration and problem solving. However, it is not many schools have adopted the living curriculum model now days. But several schools are starting to be interested in developing this curriculum model, for example at the Indonesian Kuala Lumpur School. The idea of a living curriculum at the Indonesian Kuala Lumpur School is emphasized more than two fundamental; character education and the development of skills (life skills). These two points are very important in this era. In fact, the progress of an increasingly modern era requires participants to have qualified skills with good character. It is not only to focus on score and grade in school.

\section{REFERENCES}

Abdullah, I. (2011) Pengembangan Kurikulum Teori dan Praktik. Yogyakarta: Ar-Ruzz Media.

Alfianto, E. A. (2012) 'Kewirausahaan : Sebuah Kajian Pengabdian Kepada Masyarakat', 
Jurnal Heritage, 1(2), p. 34.

https://jurnal.yudharta.ac.id/v2/index.php/HERITAGE/article/view/837/691.

Anggraini, D. A. (2018) Pembelajaran Life Skill Dengan Metode Belajar Bersama Alam

Di SD Alam Harapan Kita Klaten. Universitas Negeri Semarang. http://lib.unnes.ac.id/32640/1/1102414028.pdf.

Baruwadi, D. (2012) 'Penyelenggaraan Pendidikan Kecakapan Hidup Dalam Peningkatan

Kemandirian Pemuda', Jurnal Pendidikan Luar Sekolah, 8(1), p. 2. http://garuda.ristekbrin.go.id/documents/detail/379796.

BKPI, P. (2020) Kuliah Kerja Lapangan di Sekolah Indonesia Kuala Lumpur Malaysia.

Available at: https://www.youtube.com/watch?v=bZqI8HdkoEc.

Carina, T. and Supriyadi (2016) 'Prestasi Belajar Pada Siswa Underachiever Di Bali’, 3(1),

p.

https://ojs.unud.ac.id/index.php/psikologi/article/download/25218/16428/.

Chasanatin, H. (2015) Pengembangan Kurikulum. Yogyakarta: Kaukaba.

Grotzer, T., Vaughn, D. and Wilmot, B. (2019) The Seven Principles of Living Curriculum.

https://www.nais.org/magazine/independent-school/spring-2019/the-seven-

principles-of-living-curriculum/.

Hayati, A. A. (2015) 'Pendidikan Nilai Moral Melalui Program Living Values Activities

Dalam Pengembangan Karakter Siswa Di SMA Plus Muthahhari Bandung', Jurnal Pendidikan Ilmu Sosial, 23(1), pp. 80-87.

https://ejournal.upi.edu/index.php/civicus/article/download/2893/1926.

Hiryanto (2017) 'Pedagogi, Andragogi dan Heutagogi Serta Implikasinya Dalam

Pemberdayaan Masyarakat', Dinamika Pendidikan, 22(1), p. 65.

https://journal.uny.ac.id/index.php/dinamika-

pendidikan/article/view/19771/10802.

Kanal Infomasi (2020) Pengertian Konsep Living Curriculum. Available at: https://www.kanalinfo.web.id/pengertian-konsep-living-curriculum.

Latifah, L. and Ritonga, I. (2020) 'Systematic Literature Review (SLR): Kompetensi Sumber Daya Insani Bagi Perkembangan Perbankan Syariah Di Indonesia', $A l$ Maal: Journal of Islamic Economics and Banking, 2(1), p. 67. doi: 10.31000/almaal.v2i1.2763.

Lismina (2018) Pengembangan Kurikulum di Sekolah dan Perguruan Tinggi. Jawa Timur: Unwais Inspirasi Indonesia.

Mariani, D. (2020) Tanya Jawab Living Curriculum Sekolah Indonesia Kuala Lumpur. 
https://www.youtube.com/watch?v=K9pEWyhKess.

Martanti, F. (2017) 'Penanaman Nilai-Nilai Kejujuran Melalui Media Kantin Kejujuran Di Pondok Pesantren Al Hikmah Semarang', Sosio Dialetika-Jurnal Ilmu SosialHumaniora, 2(1), p. 51.

https://publikasiilmiah.unwahas.ac.id/index.php/SD/article/view/1812/1860.

Moh. Faizin, N. F. E. (2019) 'Implementasi Lvep (Living Value Education Program) Di Madrasah Ibtidaiyah Manbaul Ulum Mojopuro Gede Bungah Gresik', Journal of Islamic Elementary School, 4(1), p. 2018.

http://jies.uinsby.ac.id/index.php/jies/article/view/44.

Mustoip, S., Japar, M. and Ms, Z. (2018) Implementasi Pendidikan Karakter. Surabaya: CV. Jakad Publishing.

Omeri, N. (2015) 'Pentingnya Pendidikan Karakter Dalam Dunia Pendidikan', Jurnal Manajer Pendidikan, 9(3), pp. 464-468. https://ejournal.unib.ac.id/index.php/manajerpendidikan/article/view/1145/953. Partono (2020) 'Pendidikan Akhlak Remaja Keluarga Muslim di Era Industri 4.0', Dirasah : Jurnal Studi Ilmu dan Manajemen Pendidikan Islam, 3(1), p. 59. doi: 10.29062/dirasah.v3i1.78.

Septikasari, R. and Frasandy, R. N. (2020) 'Keterampilan 4C Abad 21 dalam Pembelajaran Pendidikan Dasar', Tarbiyah al-Awlad, 8(2), pp. 108-111. https://ejournal.uinib.ac.id/jurnal/index.php/alawlad/article/download/1597/119 6.

Tremont, S. (2017) A Living Curriculum. http://www.tremontschool.org/Home/theliving-curriculum/.

Wahab, R. (2012) 'Reformulasi Inovasi Kurikulum: Kajian Life Skill Untuk Mengantarkan Peserta Didik Menjadi Warga Negara Yang Sukses', Ta'dib, 17(02), pp. 219-220. doi: 10.19109/tjie.v17io2.33.

Wulandari, V., Koryati, D. and Fitriyanti (2016) 'Pelaksanaan Pendidikan Life Skills Dalam Program Wirausaha Siswa Kelas XI SMA Negeri 5 Palembang', Junal Profit, 3(2), p. 176. https://ejournal.unsri.ac.id/index.php/jp/article/view/5569/3006.

Yusuf, A. M. (2014) Metode Penelitian Kuantitatif, Kualitatif, dan Penelitian Gabungan. Jakarta: Kencana.

Zafi, A. and Partono (2020) Penguatan Pendidikan Karakter Melalui Ektrakurikuler Keislaman. https://doi.org/10.31219/osf.io/sxfbd. 